\title{
An Assessment of e-Book Collection Development Practices among Romance Language Librarians
}

\author{
Betsaida M. Reyes \\ University of Kansas, Lawrence, KS, USA \\ Frances A. Devlin \\ University of Kansas, Lawrence, KS, USA
}

\begin{abstract}
Purpose - The purpose of this paper is to describe the collection development practices regarding ebooks among librarians who manage French, Italian, Portuguese and Spanish (Romance) materials. The authors aim to describe factors that influence acquisition of e-books for Romance language collections; to confirm librarians' perception that humanities researchers prefer print and library administrators' attitudes towards e-books.

Design/methodology/approach - The study collected data using a mixed method approach of a survey and focus groups.

Findings - The study confirms that user preference is the primary consideration of Romance librarians in selecting e-books. Contrary to librarians' perceptions, the study found that humanities faculty and students are not averse to using e-books for specific purposes such as searching, targeted reading, and course materials. While restrictions on lending e-books are a concern, Romance librarians are focused primarily on serving the needs of their core constituencies.

Research limitations/implications - The practice of adding call numbers to individual e-books varies among institutions. Individual e-book titles in large packages do not necessarily get added to the catalog, thus making it very difficult to compare e-book collections between institutions.

Originality/value - This study endeavors to unify the anecdotal narratives and factors that influence the acquisition of e-books by Romance librarians.

Keywords Collection development, Mixed-methods assessment, e-books, Romance languages, Romance literature, Humanities, User preference, Screen Reading

Paper type Research paper

\section{Introduction}

Since the invention of the e-book with the creation of Project Gutenberg by Michael Hart in 1971 (Lebert 2010), library collections have gradually been shifting from print to electronic format. While the literature on e-books is extensive, there are few studies that deal with perspectives and practices of librarians who collect materials in French, Italian, Portuguese, and Spanish languages and literatures [hereafter referred to as Romance librarians, Romance languages, or Romance materials] for academic research libraries. The authors were interested in collecting data on factors that influence Romance librarians when deciding to purchase e-books. Additionally, the authors sought to explore humanities researchers' perceived preference for print materials and library administrators' influence in promoting increased access to electronic collections.
\end{abstract}




\section{Literature Review}

E-books are becoming increasingly ubiquitous in library collections across the nation. Their growing popularity is only matched by the array of licenses, purchase models, and varying platforms offered by vendors. Librarians are often faced with the challenge that e-books are not enjoying the same success as e-journals. Ashcroft (2012, p. 405) points to "the need for libraries to raise awareness about the ebooks they offer and how they offer them." There are many myths surrounding the benefits of e-book collections (Frederick 2015) and there is a lack of user awareness that renders them invisible (LaMagna, Hartman-Caverly \& Danowitz 2015) as they are dispersed over various platforms. In a literature review on the adoption of e-books, Kahn and Underwood (2013) concluded that for libraries to grow their ebook collections, it is crucial that they understand the business models and select the best one to fit their individual needs.

Murray $(2018$, p. 21) confirms librarians' intuition that humanities faculty "perceive that printed books are more valuable in their disciplines." In his study at the University of Denver, Levine-Clark (2007, p. 13) found that faculty in humanities are aware of e-books, but they "prefer print for reading of longer passages ... and only use the electronic version as a backup when the print is not available." However, recent published literature suggests a growing consensus that humanists are becoming more open to using e-books than anecdotal evidence and professional instinct would suggest (Dahl 2013). Another paper (Carroll et al., 2016, p. 149) found that "a large portion of academic library users across affiliate statuses and subject disciplines have grown comfortable with e-book versions of conference proceedings, reference materials, and style guides." Carlock and Maughan Perry (2008) also found that faculty were generally open to the concept of using e-books for teaching or as reference sources. Yet many users are dissatisfied with the interfaces, platforms, and digital rights management (DRM) imposed by many of the e-book publishers and aggregators. User surveys carried out by Chrzastowski and Wiley (2015, p. 184) "revealed the clear recognition of the value and convenience of e-books and also illustrated the frustration still experienced when electronic cannot emulate print."

While e-books represent many exciting opportunities, there are also many challenges. Unlike their paper counterparts, sharing e-books via interlibrary loan (ILL) is almost impossible due to licensing restrictions. A way to circumvent these challenges may be through "short-term lending, purchase on demand and print on demand" (Wicht 2011, p. 205). The biggest hurdle to lending e-books may be that vendors are 
still working out the sustainability of their business models (Vasileiou, Rowley \& Hartley 2012). While waiting for a vendor-led solution, libraries could work collaboratively to create a "global, universal library, collecting materials in all languages and cultures, open to all" while at the same time, working to close the access gap and increase discoverability of our digital collections (Wu 2019, p. 132). Walsh (2016), writing about the differences in paper and screen reading in a literature review of over 200 articles, notes that "recent studies suggest that speed and recall differences between media are insignificant (p. 160)."

\section{Methodology}

The authors used a mixed methods approach to collect data through a survey and focus groups. The objectives of this project were to:

- Describe the collection development practices and factors that influence acquisition of e-books among Romance librarians;

- Investigate the perception of print preference by humanities researchers; and

- Explore library administrators' vision of e-books to increase online access to research materials.

For the survey, authors compiled a list of Romance librarians working in Association of Research Libraries (ARL) institutions. This resulted in a population of 184 librarians (including the authors). The survey was distributed in July 2017 using Qualtrics and received a total of 76 responses $(41.3 \%$ response rate). The survey was comprised of 16 questions (see Appendix I), with a mix of closed and open-ended questions, multiple choice, and Likert scale. At the end of the survey, respondents had the opportunity to opt-in if interested in participating in a focus group. This approach allowed the authors to pose additional questions to gain further insights into the librarians' perspectives on collecting e-books. Once IRB permission was secured, the authors convened two focus groups of three to four participants in each group via Skype for Business. Participants were asked 10 open-ended questions (see Appendix II) and the sessions were audio recorded and transcribed.

\section{Findings and Discussion}

\section{Survey}

Selection and Acquisition. When asked if their libraries had an e-book collection development policy, 21 (41\%) librarians indicated "yes", 19 (37\%) indicated "no", and 11 (22\%) indicated "not sure". The numbers are almost evenly divided between "yes" and "no" and perhaps is indicative of the 
conservative nature of academic libraries in formalizing collection policies for e-books. While e-books are becoming more popular, librarians continue to purchase print materials based on traditional practices. It is important to note that this question was framed for overall collections, and not only for Romance languages. Librarians were asked to rank the importance of various factors (see Figure 1.) when ordering e-books. User preference was clearly ranked as the most important consideration. The second highest ranked factor was whether it was being used as a course book. Collection development policies are not considered an important factor in making decisions regarding e-books, as $49 \%$ of participants selected "neutral".

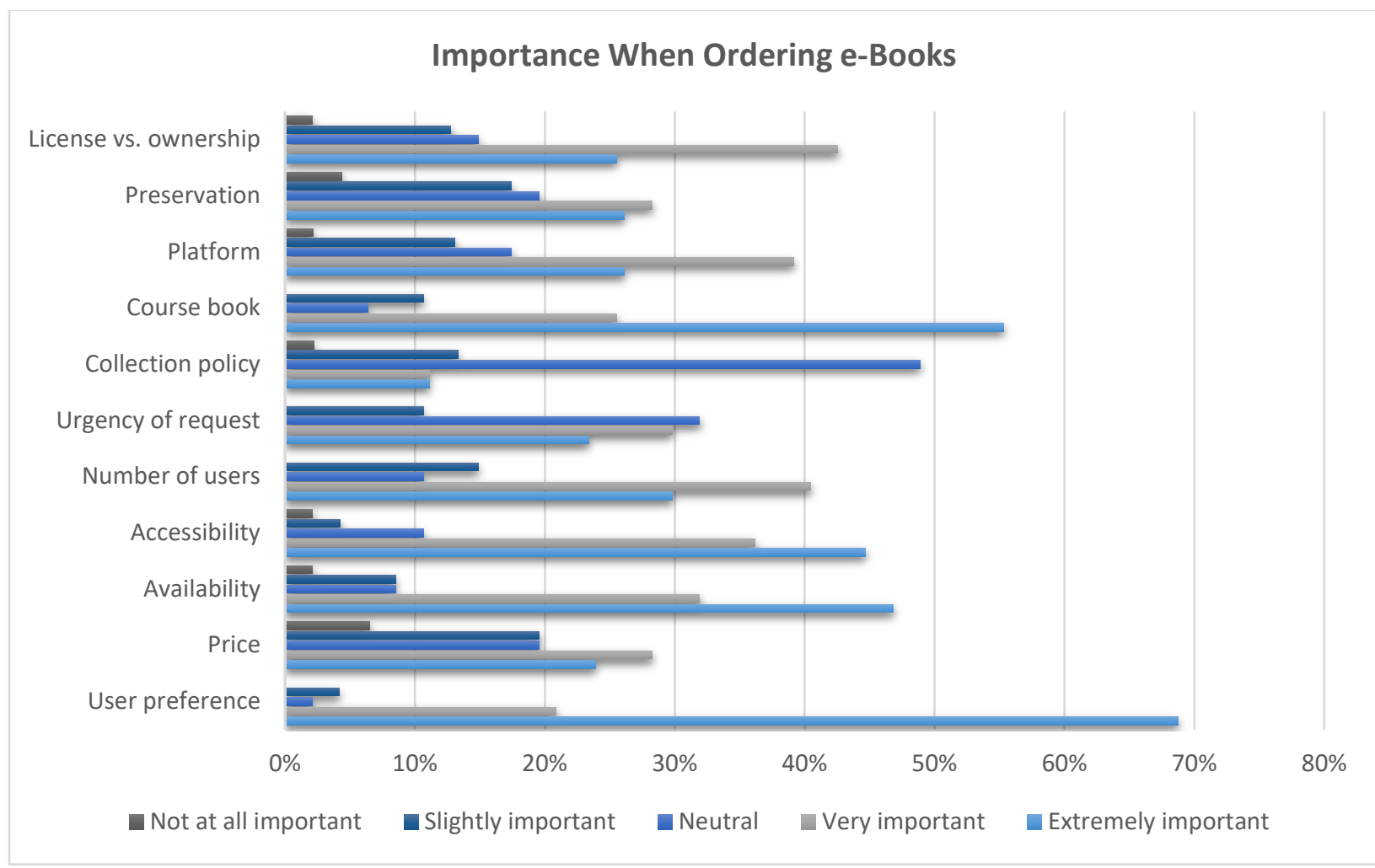

Figure 1.

Subject expertise. When librarians were asked about how they acquired e-books, 46 (32\%) indicated firm orders, 39 (27\%) indicated that they add Open Access (OA) titles, 29 (20\%) librarians indicated using Demand Driven Acquisitions (DDA), 23 (16\%) indicated using Approval Plans, with the remaining 9 (6\%) using other methods. This question was a "select all that apply", so the results reflect the most commonly used methods. If we consider firm orders and OA books as title-by-title selection of e-books, that means librarians are adding individual e-books at a very high rate. This is important because while e-books packages continue to get bundled as part of databases, Romance librarians continue to select 
individual titles for the collections. When asked to select all vendors used to acquire e-books, 34 (30\%) participants indicated they use GOBI Library Solutions from EBSCO, 19 (17\%) indicated using Casalini, 15 (13\%) use Amalivre, 12 (11\%) use Digitalia, 8 (7\%) selected both Coutts and Harrassowitz respectively, 3 (3\%) selected E-libro, and $14(12 \%)$ selected "other". While GOBI is the most common vendor used, the lower percentages for other vendors may be indicative of the slower pace of e-book publishing for Romance languages. When librarians were asked if their institutions would add OA e-books to the catalog based on their recommendation, 36 (73\%) responded "yes". This is another measure indicating the importance of subject expertise because librarians manage OA titles by choosing to add them to the catalog, as they do firm orders. When questioned in what sources they find OA titles, 14 (24\%) indicated CAIRN, 10 (17\%) selected all CLACSO, FLACSO, Open Library and OpenEdition Books at an equal rate, with 4 (7\%) indicating "other". It is clear that librarians view these organizations as trusted sources for high quality research content because most are associated with reputable, established academic publishers or non-government institutions for Romance language materials.

User preference. When librarians were asked (cost aside) if they would consider purchasing more ebooks, 34 (71\%) overwhelmingly answered "no". In the comments, respondents provided more details on why e-books were not always a great option. Preference for print was echoed by several participants, as illustrated in this comment. "Scholars making deep use of a monograph report (still) a preference for print -- if they're in town, that is." This highlights the librarian's dilemma in choosing the right format for their users' needs. Another participant commented on the tension between the administrative vision and the librarian's knowledge of immediate needs of the user. "If cost were not a concern, I still wouldn't choose more e-books in large part for expressed preference for print from my faculty and students as well as, well, frankly, being a thorn in the side of administration who seems intent on purging as much print material as possible." Lastly, one participant noted poignantly the reality of lasting ownership of the electronic formats: "E-books tend to cost more than the print version, and depending on method of acquisition, might not be retained permanently." Additionally, librarians were presented the following scenario: "A user requests a book, and it is available in both print and electronic format, what would you do?" 33 (69\%) participants indicated that they would ask the user for their preference. $8(17 \%)$ said they would purchase the print, $2(4 \%)$ indicated that they would purchase the e-book, and 4 (8\%) indicated "other". Comments for this question included concerns such as costs, platforms, and accessibility across multiple campuses. 
Cooperative efforts. When librarians were asked if their institution participates in any cooperative collection development efforts to acquire e-books, 23 (48\%) responded "yes", 17 (35\%) said "no", and 8 (17\%) were "unsure". The authors were surprised by the high number of cooperative efforts that existed. However, the open comments for this question revealed that many of the cooperative efforts described include large e-book packages, DDA, or university press e-book collections. Further, many of these cooperative arrangements were regional consortia agreements that focus on English language materials. This illustrates one of the challenges for Romance librarians in selecting e-books. Publishers of Romance language materials are generally located outside of the United States and their output represents a small subset of the overall collections in ARL Libraries. The authors would like to note one known exception: the MaRLI project (Manhattan Research Library Initiative) which "seeks to increase the visibility of low-use materials" (Carreño and Maltarich 2016).

E-book dilemma. Librarians were asked to indicate how strongly they agreed or disagreed with a series of statements (see Figure 2.) regarding Romance language collections.

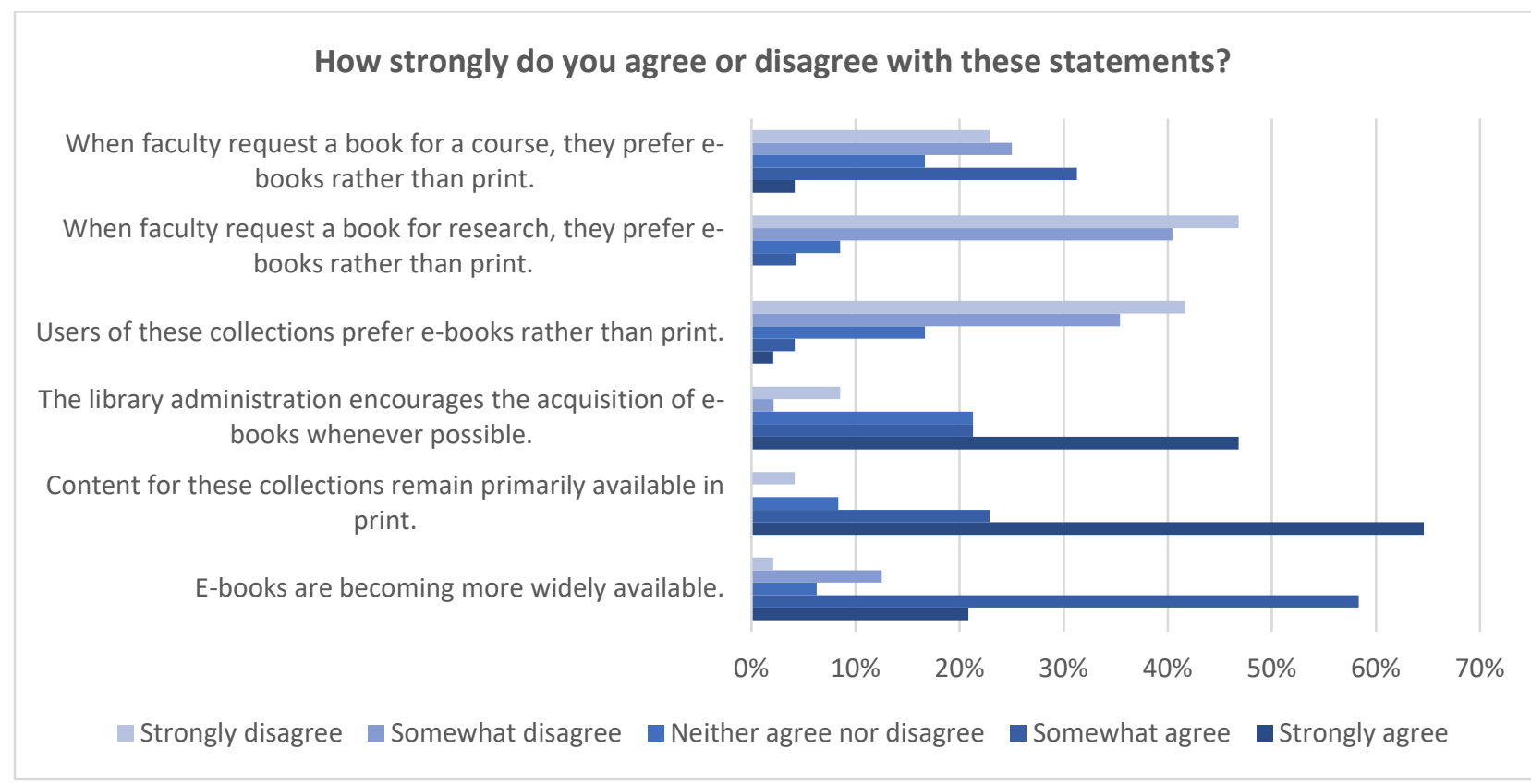

Figure 2.

Librarians' perception of the field is that print is still the main choice, although e-books are sometimes preferred for course materials. There is strong agreement (47\%) with the statement that there is pressure by the administration to add more e-books to the collections. Despite all of that, librarians 
seem unified ( $58 \%$ somewhat agree and $21 \%$ strongly agree) in the sentiment that e-books are becoming more available in Romance languages.

\section{Focus groups}

Licenses and ILL. E-book licenses are constantly changing and becoming more restrictive making it almost impossible for librarians to keep current. The majority of participants indicated that they consult with acquisitions or e-resources staff to determine which license is best suited for their needs. Some alluded to guides created by the electronic resources department to streamline the decision-making process. For others, the final decision is determined by cost. One librarian commented how "[we] only buy things we can get perpetual access to, we don't license". These comments indicate that librarians are very concerned about licenses, as much as they are about costs. Most participants commented that they do not often think about the implications on ILL when purchasing an e-Book. "I do feel badly when I buy e-books and I can't share them, but my first priority is to my constituents." This highlights the dilemma that librarians face between making information accessible to the public and serving the immediate needs of local users.

Space concerns. The use of physical space in libraries continues to transform in favor of creating more individual and collaborative spaces. In order to offer similar levels of access to research resources, ebooks seem to be an ideal solution. One participant commented that "we are not getting any new space...so there is a tremendous pressure not to increase our book footprint." With the reality of space limitations and lack of off-site storage for growing collections, some institutions have implemented epreferred acquisitions policies. Due to limited availability or licensing restrictions for publications in Romance languages, e-preferred is not always an option. The pressure from administration can cause tension for Romance librarians. Another participant commented "...the library administration has told us to buy e-books unless specifically requested by faculty to do otherwise." Often the reduction of the print collection is part of strategic planning processes to increase more user-centered space. In a case study at the University of Texas at Tyler, the print collection was reduced by half to support their growing enrollment both on-campus and online. In order to support the former group, spaces around campus needed to be reconfigured and for the second, the library's collection needed to focus on adding more e-books (Acadia 2016).

Cost of textbooks. Nationwide, there is a strong push to make higher education more affordable by using open source textbooks. A majority of librarians indicated that their institutions are engaged in activities 
to lower the costs of textbooks and that it is a top priority with varying degrees of involvement from libraries. Lowering the costs of textbooks can be achieved in several ways. One librarian reported that their library has "taken all the general education courses and put those textbooks on reserve for checkout." Many institutions provide grants to encourage the adoption, adaptation, or creation of open education resources (OER) to lower the cost of course materials. These grants, as well as serving as an incentive, also "allow [faculty and lecturers] to get some recognition from a lot of the work that they've already done to bring down the costs of course materials for the students." When adapting or creating an OER is not feasible for a course, e-books can help bridge the gap by reducing the overall cost of the class. When librarians were asked if they had purchased an e-book that was a required reading material for a course, four indicated that they "have" and three said that they "have not". One elaborated that they had worked on an affordability grant where they "purchased several items that were at single-user license to become multi-users."

Remote access. As university campuses become more interconnected in a globalized world, there has been an increase in online learning offerings. One participant noted how e-books are assisting a large contingency of "online and commuter students." Librarians still contend with the variety of licenses available and implications for library collections. One participant commented that "remote access is key and if you don't have it you might as well not have the e-book in [their] opinion." At the same time, more users are engaging in research away from campus, while on sabbatical or researching in other countries. "I have a couple of faculty... who often say that they prefer electronic format even for monographs...and they have mentioned "I really like e-books when I am traveling."

Format preferences. Participants commented on users' enthusiasm about the potential of e-books. One librarian commented how faculty “were very excited about e-books until they couldn't print the whole thing." One librarian commented that e-books are "a necessary evil" that help users avoid "a recall war [when] you just need to get access to that one page." However, the very technology that makes them appealing in the first place ends up being a disappointment for both the user and the librarian. As an example, when faculty try to "integrate [e-books] in their teaching and research...it just becomes cumbersome...then [it's] one more thing you have to train them to use. It can be more of a hassle than it's worth." Romance librarians are caught in between the users' needs and library administrators as summarized by a participant when they stated that "anyone [who] is not familiar with Latin American materials. E-books just aren't available...there is a lack of awareness from the part of the administrators." 
Locating e-books. While e-books do not take any physical space in the stacks, they still need to be counted. When librarians were asked if their institutions retain call numbers in the records, the majority said "no". Some indicated that they do keep the call number, but that it also has a link that indicates that the title is available online. The authors' institution suppresses e-books call numbers, thus they are not visible in the library catalog records. The authors investigated this issue further with a cataloguer, and an electronic resources librarian at their institution and learned that there is some disagreement among librarians about the usefulness of having call numbers visible for e-books. On the one hand, an argument could be made that call numbers, even if suppressed, could be useful in collection assessment projects as it would allow librarians to determine the total number of e-books in their collections. On the other hand, WorldCat collection assessment projects have proved to not be so reliable in calculating the size of collections by subject areas. Lastly, some librarians agree that retaining call numbers in the records could cause confusion among patrons who may think that the library owns a print copy of the book in question, even if this records also displays a link to connect to the electronic version.

\section{Conclusion}

The authors approached this study with an assumption that e-books in collections would be easy to quantify. However, it soon became apparent that many libraries do not retain call numbers for individual e-book titles in the catalog. In addition to budget considerations, the findings from the survey and focus groups confirmed that user preferences, space, remote access, and providing lower cost course materials are significant factors in deciding what format to buy. Some users are excited by the potential of enhanced and interactive learning that e-books can provide.

As library space become scarce, there is increasing pressure from library administrators to acquire more e-books in all subject areas. Since e-books may be dispersed over various platforms, they run the risk of being invisible to researchers. The authors found that there is a growing number of cooperative collection development agreements for e-books, but almost all focus on English language materials. An exception to this is the MaRLI project.

The data confirmed that while humanities researchers continue to have a strong preference for print, their attitudes are beginning to change. They are open to using e-books for some types of materials (such as, style guides, reference books, or textbooks) with monographs being a significant exception. The question of the print book's materiality as a defining characteristic, making it superior to its 
electronic counterpart, is an area the authors believe deserves more attention. As technology continues to advance and younger generations are habituated to reading and consuming information online on their phones and other handheld devices, how will this affect the perception of the print book? Is the perception of reliability going to shift?

The data also support another conclusion: print books are viewed as superior sources in the humanities compared to e-books. This perception is rooted in traditional thinking and is reminiscent of the arguments against OA journals somehow being less reliable or authoritative, in contrast to those published under the traditional model of paid subscriptions. The authors agree that it is important that libraries facilitate access to both print and e-books while also providing users with "spaces for deep thought; further librarians should not "dismiss the paper form... particularly in universities that aim to equip their graduates with critical thinking and independent learning skills (Walsh, 2016, p.170-171)." Academic librarians are well positioned to help balance evolving users' reading behavior while continuing to build relevant research collections for the future. 


\section{References}

Acadia, S. (2016), “Books Be Gone! Reducing an Academic Library's Print Collection by Half to Meet Strategic Planning Initiatives and Participate in a Joint Library Resource-Sharing Facility", Journal of Library Administration, Vol. 56 No. 2, pp. 144-157. https://doi.org/10.1080/01930826.2015.1105668

Ashcroft, L. (2011), "Ebooks in libraries: An overview of the current situation", Library Management, Vol. 32 No. 6/7, pp. 398-407. https://doi.org/10.1108/01435121111158547

Carlock, D. M., and Maughan Perry, A. (2008), "Exploring faculty experiences with e-books: A focus group", Library Hi Tech, Vol. 26 No. 2, pp. 244-254. https://doi.org/10.1108/07378830810880342

Carreño, A. and Maltarich, W. (2016), "Cooperative collection development: the Manhattan Research Library Initiative, electronic books, and the scholarly monograph at risk ", in Hale, D. (Ed.), In Shared Collections: Collaborative Stewardship, ALA Editions, Chicago, IL, pp. 109-123.

Carroll, A. J., Corlett-Rivera, K., Hackman, T., and Zou, J. (2016), "E-Book Perceptions and Use in STEM and Non-STEM Disciplines: A Comparative Follow-Up Study", Portal: Libraries and the Academy, Vol. 16 No. 1, pp. 131-162. https://doi.org/10.1353/pla.2016.0002

Chrzastowski, T. E., and Wiley, L. N. (2015), "E-book Use and Value in the Humanities: Scholars' Practices and Expectations", Library Resources \& Technical Services, Vol. 59 No. 4, pp. 172-186.

Dahl, C. (2013), "PDA and the humanities: Assessing the fit through an examination of the literature on humanists and e-resources", The Electronic Library, Vol. 31 No. 6, pp. 745-752. https://doi.org/10.1108/EL-05-2012-0051

Frederick, D. E. (2015), "On eBooks in academic libraries: An article based on a presentation at the Library 2.014 Conference", Library Hi Tech News, Vol. 32 No. 5, pp. 12-15. https://doi.org/10.1108/LHTN-02-2015-0015

Kahn, M., and Underwood, P. G., (2013), "Issues related to the adoption of e-books in academic libraries: A literature review", South African Journal of Libraries and Information Science, Vol. 79 No. 2, pp. 10-17. https://doi.org/10.7553/79-2-141

LaMagna, M., Hartman-Caverly, S., and Danowitz, E. S. (2015), "Integrating e-Books into Academic Libraries: A Literature Review”, Internet Reference Services Quarterly, Vol. 20 No. 1-2, pp. 19-32. https://doi.org/10.1080/10875301.2015.1049396

Lebert, M. (2010), Project Gutenberg (1971-2009). Retrieved from http://www.gutenberg.org/cache/epub/31632/pg31632-images.html

Levine-Clark, M. (2007), "Electronic Books and the Humanities: A Survey at the University of Denver. Collection Building, Vol. 26 No. 1, pp. 7-14. https://doi.org/10.1108/01604950710721548

Murray, D. C. (2018), "Humanities E-Books: An Affective Faculty Survey”, Collection Management, Vol. 43 No. 1, pp. 3-27. https://doi.org/10.1080/01462679.2017.1360230

Vasileiou, M., Rowley, J., \& Hartley, R. (2012), "Perspectives on the future of e-books in libraries in universities", Journal of Librarianship and Information Science, Vol. 44 No. 4, pp. 217-226. https://doi.org/10.1177/0961000611434759

Walsh, G. (2016), "Screen and Paper Reading Research - A Literature Review". Australian Academic and Research Libraries, Vol. 47 No. 3, pp. 160-173. https://doi.org/10.1080/00048623.2016.1227661 
Wicht, H. (2011), "The Evolution of E-books and Interlibrary Loan in Academic Libraries", Collaborative Librarianship, Vol. 3 No. 4. Retrieved from http://digitalcommons.du.edu/collaborativelibrarianship/vol3/iss4/4

Wu, M. M. (2019), "Shared Collection Development, Digitization, and Owned Digital Collections", Collection Management, Vol. 44 No. 2-4, pp. 131-145. https://doi.org/10.1080/01462679.2019.1566107 


\section{Appendix I. Survey}

1. Please provide the following demographic information:

○ Language/Literature Responsibilities

○ Institutional Affiliation

2. What is the annual firm order and approval plan budget allocated for the following subjects at your institution?
○ French
O Italian
- Portuguese
○ Spanish

3. Does your institution have a collection development policy for the acquisition of e-books?
- Yes
○ No
- Not sure

4. What method(s) do you use to acquire e-books for your subjects? Select all that apply:

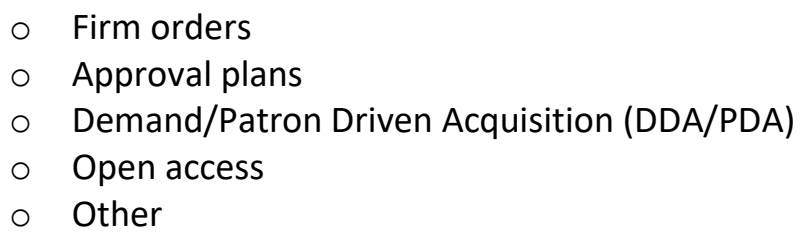

5. What vendors do you use to acquire e-books for your subjects? Choose all that apply:
○ Amalivre
- Casalini
○ Coutts
- Digitalia
O E-libro
- GOBI Library Solutions from Ebsco
- Harrassowitz
- Ventara (Garcia Cambeiro)
o Other

6. Based on your recommendation, does your institution add open access e-books in your subjects to your library catalog?
- Yes
- No
- Not sure 
7. In what sources (i.e., platforms or publishers) do you find open access e-books for your subjects to add to your institution's catalog? Choose all that apply.
- CLACSO
- FLACSO
- CAIRN
- Open Library
- OpenEdition Books
O Other

8. Does your institution participate in any cooperative collection development efforts with other institutions to acquire e-books?
○ Yes
○ No
- Not sure

9. Please briefly describe your institution's cooperative collection development efforts for e-books.

10. How important are the following factors when placing firm orders for single titles of e-books? Select all that apply.
- License vs. ownership
- Preservation
- Platform
○ Course book
- Collection policy
- Urgency of request
- Number of users
- Accessibility
- Availability
- Price
- User preference
a. Other

11. If cost were not a concern, would you choose more e-books than print books?
- Yes
○ No
○ Not sure

12. If more e-books were available in your subjects, would you choose more e-books over print books?
- Yes
- No
- Not sure 
13. Consider the following scenario. A faculty or student asks you to purchase a book. The title is available in both print and electronic format. What is your initial strategy to handle the request?

- Ask user for preference

- Choose least expensive option

- Purchase e-book

- Purchase print

O Other

14. Please indicate how strongly you agree or disagree with the following statements regarding collections in your subjects.

- E-books are becoming more widely available.

- Content for these collections remain primarily available in print.

- The library administration encourages the acquisition of e-books whenever possible.

- Users of these collections prefer e-books rather than print.

- When faculty request a book for research, they prefer e-books rather than print.

- When faculty request a book for a course, they prefer e-books rather than print.

15. Do you have any additional comments about the acquisition of e-books for your subjects?

16. Are you willing to be contacted for a follow-up interview regarding collection development practices for e-books?

○ Yes

○ No 


\section{Appendix II. Focus Group Questions}

1. Aside from the cost of eBooks, what other factors keep you from purchasing eBooks for your area?

2. Please share more details on the cooperative collection development for eBooks at your institutions. If your institution is not participating in a cooperative collection development effort, can you please share your thoughts on this idea?

3. Do you consider the implications on ILL when purchasing an eBook for your collection?

4. Is your institution engaged in any activities to lower the costs of textbooks?

5. Have you purchased an eBook to be used for a course as required reading material?

6. Do you consult with your acquisitions or e-resources staff to determine which license is best suited for your needs?

7. How important is remote access when purchasing an eBook?

8. Is stacks space a concern for your subject area at your institution?

9. Does your institution keep call numbers as part of the MARC record for e-books acquired via firm order purchases?

10. During your tenure at your institution, have you seen a shift in preferences or attitudes towards eBooks? 